\title{
Government Policy in the Management of Border Conflict Between Indonesia and Oecusse District, Timor Leste
}

\author{
Petrus Kase \\ Department of Public Administration \\ University of Nusa Cendana \\ Kupang, Indonesia \\ kasepetrus@yahoo.co.id
}

\author{
Lenny Magdalena Tamunu \\ Department of Public Administration \\ University of Nusa Cendana \\ Kupang, Indonesia \\ lennymkallauundana@yahoo.com
}

\begin{abstract}
This research describes the types, causes and consequences of border conflict, and government policy in the management of border conflict between Indonesia and Oecusse District, Timor Leste. Research data were obtained through indepth interview, focus groups (FGs) and document review, while data analysis used qualitative analysis technique. This research found several types of border conflict between Indonesia and Oecusse District, Timor Leste such as communal, inter-state, horizontal, latent, extraordinary, damaging, threat on state sovereignty, and threat on social order of border society from both sides. Causes of the border conflict are administrative/political history and contemporary. The border conflict also tends to destroy sosial/political relation, sociocultural values and safety among border society. Indonesia obeys adequately regulation such as "border line agreement", but has not yet used customary law to resolve the border conflict. Indonesian central government is slightly slow while provincial government of East Nusa Tenggara, and district government of Kupang and North Middle Timor are faster enough in managing the border conflict. Indonesian government is able to protect border societies and assure their safety, but less equal in determining border line in conflict segments. It has also conducted diplomacy and negotiation with Timor Leste government, but it is still unsuccessful yet to convince Timor Leste government in resolving unresolved segments. It should continuously do diplomacy and negotiation with Timor Leste government to manage and resolve the border conflict by considering simultaneously administrative/politics, border history, customary law, equity and togetherness.
\end{abstract}

Keywords-government policy, border conflict, conflict management

\section{INTRODUCTION}

Republic of Democratic Timor Leste (RDTL), usually called Timor Leste proclaimed its independence in 2002. In terms of its foreign relationship with Indonesia, it experiences border conflict especially between Oecusse District and Kupang District and North Middle Timor District. Border conflict between these districts are located in villages including: (1) Haumeni Ana, North Middle Timor District, Indonesia with Passab, Oecusse District, Timor Leste where border conflict happened on $31^{\text {th }}$ July 2012 because Timor
Leste built Customs Office, Quarantine Office and Immigration Office in sterile zone and passed through Indonesian territory along 20 meters; (2) Nelu, North Middle Timor District, Indonesia with Leolbatan/Kosta, Oecusse District, Timor Leste where border conflict happened on $14^{\text {th }}$ October 2013 because Timor Leste built road along 500 meters in Indonesian territory and passed through sterile zone along 50 meters, destroyed state border pillars and 9 ancestor cemeteries of Nelu citizen; (3) Bijaelsunan/Manusasi, North Middle Timor District, Indonesia with Oben, Oecusse District, Timor Leste where border conflict happened on $14^{\text {th }}$ October 2013 in area of 142,7Ha; and (4) Naktuka/North Netemnanu, Kupang District, Indonesia with Citrana, Oecusse District, Timor Leste in area of 1.069Ha (Hernandez, 2015).

Although Indonesian and Timor Leste government have conducted a number of policy actions to manage and resolve the border conflict, their effectiveness are still questioned because border community members from Indonesian side consider that the policy actions are incompatible with their aspiration. This research aims to describe government policies in the management of border conflict between Indonesia and Oecusse District, Timor Leste. In particular, it aims to describe the types, causes and consequences, and Indonesian government policies in managing and resolving the border conflict.

\section{THEORETICAL REVIEW}

\section{A. Concepts and Types of Policy}

There are many definitions of public policy, however, we only present some relevant definitions. According to Dye (1992), public policy is "whatever government choose to do or not to do." Kraft and Furlong (2007) also define "public policy as a course of government action or inaction in response to public problems." Lowi (1964) then classifies policy into three main typologies that are :

- Distributive policies which involve "the granting of some sorts of benefits to a particular interest group or other well-defined relatively small group of beneficiaries." 
- Regulatory policies are intended to govern business conduct. These policies can be classified into : (1) competitive regulatory policies involve policies designed to "limit the provision of goods and services to one or a few designated deliverers," and (2) protective regulatory policies that are policies that regulate some activities to protect public.

- Redistributive policies are policies that give benefits to one group by seeming to impose a dicernable cost on another groups.

\section{B. Concept of Conflict and Conflict Manajement}

Sanginga and Kamugisha (2004) define conflict as a situation which involves people or social groups which have different interests, tend to be antagonistic and have contrary influence to use scarce resources to guarantee or increase their life. Manifestation, dimension and the level of its intensity varies significantly, implicit, explicit, local, regional, national and international violence. Sanginga and Kamugisha (2004) then define conflict management as a course of mechanism and institution to prevent and resolute dispute involving negotiation, avoidance, arbitration, conciliation, adjudication, compulsion or violence. Moreover, Rahim (2001) tries to distinguish the meaning of conflict resolution and conflict management. According to Rahim (2001) conflict resolution means conflict reduction, elimination and termination and has categories such as negotiation, bargaining, mediation and arbitration, while, conflict management must not involve conflict avoidance, reduction and termination, but effective strategic design to eliminate conflict and increase the constructive function of conflict to increase organization learning and effectiveness. Rahim (2001) explains that strategic design of effective conflict management involve five styles that are :

- Integration style called "problem solving" describing high attention on himself/herself and others. This style expects collaboration among various parties through openness, information exchange, and investigation of differences to reach accepted resolution.

- Obligation assisting style called "accommodating" describing low attention on himself/herself and high attention to others. This style tries to eliminate differences, but emphasizes togetherness to satisfy other party. It has the forms of generosity, charity, and obedience towards order from others.

- Domination style called "competing" describing high attention to himself/herself but low attention to others. This style is oriented to win-lose by compulsion. Sometimes, someone like this wishes to win although make a sacrifice.

- Avoidance style called "suppression" describing low attention on himself/herself and others. This style is like delaying issues or draw himself/herself from conflict situation.
- Compromise style describes direct attention to himself/herself and others. This style involves give and take among both sides to end conflict and to make accepted decision.

\section{RESEARCH METHOD}

This research uses qualitative approach (in-depth interview, focus groups-FGs and document review) to describe the types, causes, consequences, and Indonesian government policies to manage and resolve the border conflict between Indonesia and Oecusse District Timor Leste. It was conducted in Kupang District and North Middle Timor District, especially in villages where conflict happened such as Naktuka, North Netemnanu village, Kupang District; Manusasi, Haumeni Ana and Sunsea village, North Middle Timor District, Indonesia that directly border on Oecusse District, Timor Leste.

Research subjects were customary figures, society prominent figures, village government apparatus, district government of Kupang and North Middle Timor, and provincial government of East Nusa Tenggara. They were determined by purposive sampling technique. Data collected through in-depth interview and FGs with all selected research subjects, and document review were analyzed by using qualitative data analysis technique involving : (1) reading data to identify its content; (2) coding data to identify emerging ideas; (3) classifying data according to emerging ideas; (4) reducing data; and (5) interpreting data to present its meaning.

\section{RESULT AND DISCUSSION}

\section{A. Types of border conflict between Indonesia and Oecusse District, Timor Leste}

In this research, combination of theoretical and empirical approach is applied to identify, classify and interpret the types of border conflict between Indonesia and Oecusse District, Timor Leste. Based on such combination, this research found several types of border conflict between the two countries as described below :

- From conflict party perspective, border conflict between the two countries includes : (a) conflict between member of customary society from both sides called communal conflict; and (b) such communal conflict in higher level involves the two states/governments so that there emerges the type of interstate conflict.

- From perspective of conflict party position, border conflict between the two countries is horizontal because it happens between two groups that have similar position as groups of citizen. In terms that each country must involve in conflict resolution, the conflict is not only horizontal between groups of citizen, but also horizontal between states.

- From conflict nature perspective, border conflict between the two countries is latent. Although, situation in border conflict area between the two countries is now safe, but at any time it will re- 
emerge to be a manifest conflict because there are still several points of border conflict that are unresolved yet completely.

- From sort of event perspective, border conflict between the two countries includes : (a) extraordinary conflict because it is international scale involving governments, customary figures, society prominent figures and security apparatus from both sides; and (b) damaging conflict because it can destroy social order of society from both sides who claim that they have similar custom, social and cultural values and family ties.

- From sort of threat perspective, border conflict between the two countries includes: (a) state physical conflict where it becomes a threat on state sovereignty; and (b) conflict that threatens social and cultural values because togetherness, family ties, and custom similarity of both side societies become faded and tend to destroy.

\section{B. Causes and consequences of border conflict between Indonesia and Oecusse District, Timor Leste.}

From the nature of problem, root causes of border conflict between Indonesia and Oecusse District, Timor Leste are adequately complex, can be contemporary and historical administrative/politics. When thought accurately, causes of historical administrative/politics exactly become the basis of emerging causes of contemporary conflict.

In terms of historical administrative and politics, within colonial period, Dutch and Portuguese made agreement to divide Timor island into two parts where West Part became Dutch colony region and East Part became Portuguese colony region plus Oecusse District in West Part of Timor island as an enclave region. Agreement of the two colony countries was conducted through international arbitration trial located in Paris. Then on 1st October 1904, they produced a convention namely "A Convention for the Demarcation of Portuguese and Dutch Dominions on the Island of Timor". This convention determined border line area of the two colony countries which then became an important guide in resolving border problem not only by Dutch and Portuguese within colonial period, but also when Timor Leste integrated to Indonesia in 1976, and disintegrated from Indonesia in 1999.

When Timor Leste became one of Indonesian provinces in 1976, provincial border determination at that time at several border areas did not follow 1904 Treaty, however, border line determination of East Timor province at that time changed. When East Timor proclaimed its independence in 2002, border line determination between Indonesia and Timor Leste followed the provincial border determination between East Nusa Tenggara province and East Timor province. Customary figures and society prominent figures from Indonesian side disagree with this border determination because their customary land now become Timor Leste own. Such case happens in Haumeni Ana and Manusasi village, North Middle Timor District, and Naktuka, North Netemnanu village, Kupang District, Indonesia.
This research also found contemporary causes of border conflict between the two countries including :

- Claim regarding customary land in the border region from each side community members.

- Border pillar violation and illegal occupancy in Indonesian territory by Timor Leste. This cause happens in Haumeni Ana, Sunsea, Nelu and Manusasi village, North Middle Timor District; and Naktuka, North Netemnanu village, Kupang District, Indonesia.

- Robbing of Indonesian citizen property by Timor Leste citizen such as cows amounted to 14. This cause happens between Nelu village, North Middle Timor District, Indonesia and Leolbatan, Kosta village, Oecusse District, Timor Leste.

- Damaging activities by Timor Leste citizen towards some properties of Indonesian citizen. New farm opening and bush burning by Timor Leste citizen in border line Leolbatan, Kosta village have resulted in fire spreading in Nelu and Sunsea village, North Middle Timor District, Indonesia so that burnt hundred of betel vine trees and another commercial plants that are income sources of Indonesian citizen in the two villages.

- Infrastructure development by Timor Leste that is unacceptable by Indonesian citizen because the infrastructures are at or pass through sterile zone that is free zone where both Indonesian and Timor Leste sides are unallowed to do any activities in that zone. The infrastructure developments are found in Naktuka, North Netemnanu village, Kupang District, including immigration office, agriculture office, meeting hall, warehouse, rice mill, irrigation channel, road along irrigation channel, church and electrical circuitry. Timor Leste citizens who live in Naktuka also increases from 53 households to 63 households with family members are 135 persons (KBR, 11th June 2016). Timor Leste also developed road in Nelu village, North Middle Timor District, Indonesia in 2013 which passed through Indonesian territory along 500 meters and sterile zone along 50 meters. The road development destroyed state border pillars, storehouse of border security post and 9 ancestor cemeteries of Nelu village citizen.

- Removal of man made border pillars and natural geographic pillars unilaterally by Timor Leste without care with border rule/law. This happens in Nelu village, North Middle Timor District where Timor Leste makes disappear several man made border pillars based on 1904 Treaty, then build road along 500 meters which enters Indonesian territory and passes through sterile zone along 50 meters. Also if natural geographic pillars changes because of river flow removal, called "noe sako", Timor Leste claims that state border follows the river flow removal. Customary figures and society 
prominent figures from Indonesia disagree with this claim because the river flow removal enters Indonesian territory. This happens in Naktuka, Kupang District where there is Noelbesi river flow which usually moves every raining season.

- Determination of state border pillars by government of both sides without involving customary figures and society prominent figures. This action is rejected by customary figures and society prominent figures from Indonsian side because it is incompatible with border pillars made by ex-kingdom Amfoang from Indonesian side and ex-kingdom Ambenu from Timor Leste side in 1846, and 1904 Treaty.

Border conflict between Indonesia and Oecusse District, Timor Leste, has also resulted in : (1) illegal land struggle in Naktuka, North Netemnanu village, Kupang District (1069Ha), and Bijaelsunan, Manusasi village, North Middle Timor District $(142,7 \mathrm{Ha})$ and other segments; (2) disturbance of security situation in border area; (3) the weakening of relationship, family ties and togetherness among border community members from both sides; (4) threat of loosing some parts of Indonesian territory because of Timor Leste occupation; and (5) disturbance of social, political and economic relationship between Indonesia and Timor Leste.

\section{Types of government policies in the management of border conflict between Indonesia and Oeccuse District, Timor Leste.}

Types of government policies in managing and resolving border conflict between Indonesia and Oeccuse District Timor Leste in this research involves regulation implementation patterns, conflict resolution speed, security assurance and conflict resolution equity. Regulation regarding border line between Indonesia and Timor Leste includes 1904 Treaty, agreement of border pillar or sterile zone between Indonesia and Timor Leste in 2005, and customary law. When Timor Leste became an Indonesian province in 1976, Indonesian government changed border line at several border area of East Timor province so that border line at that time did not follow exactly 1904 Treaty. Because of this change, border line of East Timor province at that time entered some parts of Indonesian territory especially in Haumeni Ana and Manusasi village, North Middle Timor District, and Naktuka/North Netemnanu village, Kupang District. When East Timor province disintegrated from Indonesia and became a new country called Timor Leste in 2002, the territory of East Timor province automatically became Timor Leste own. Community members from Indonesian side at that all conflict villages disagree with this territory determination and require Indonesian government to use 1904 Treaty because the Treaty is more compatible with their customary law.

Also, when several border areas between Indonesia and Timor Leste were disagreed yet, the two governments decided an agreement note regarding neutral/sterile zone in 2005. This agreement contains a clause that every border area between the two countries that its border line is disagreed yet, governments and society members in that border area must not do any activities there. In fact, Timor Leste citizens disobey the agreement note so that there happens some violations in the above mentioned border areas.

Beside regulations mentioned above, district government of Kupang and North Middle Timor, customary figures and society prominent figures acknowledge the existence of customary law. According to them, community members from both sides usually obey the customary law because they have similar custom and belief that customary law violation will result in disaster and death. Therefore, resolving the border conflict areas by using customary law will be more effective than positive law and resolution of the border conflict does not have to use positive law. They suggest to Indonesian central government to apply customary law to resolve the border conflict, but this suggestion is not yet responded well.

Moreover, according to customary figures and society prominent figures in the border conflict region, Indonesian central government is slower than District government of Kupang and District government of North Middle Timor in responding or resolving the border conflict. Slow respond from Indonesian central government might be because the border conflict issue has not been yet the agenda priority of central government, meanwhile historical fact, customary law and claim of border society members are not so powerful to convince the central government.

Placement of security apparatus such as Indonesian police and Indonesian National Army, and Polícia Nacional de Timor Leste/PNTL, and Falintil-Forças de Defesa de Timor Leste/F-FDTL in the border line of both sides is a symbol of security assurance. In fact, security apparatus from both sides are successful in maintaining safe situation, protecting border society, and preventing the border conflict continuation so that not cause more human and property victim.

Indonesian citizens who live in border line also hope that Indonesian government will determine fairly the border line of the two countries, however, they assume that in the mean time, Indonesian government is less fair in that case. There are several segments of border conflict that according to them are unresolved yet equally such as Bijaelsunan, Manusasi village and Haumeni Ana village, North Middle Timor District, and Naktuka, North Netemnanu village, Kupang District. According to them, the border determination is incompatible with 1904 Treaty and customary law that bind border society members from both sides.

\section{Government policy actions in managing and resolving the border conflict between Indonesia and Oecusse District, Timor Leste}

According to Raharjo (2013), Indonesian government has taken some policy actions to manage border conflict between Indonesia and Oecusse District, Timor Leste, both short term actions (conflict resolution) and long term actions (resolution of conflict causes). Short term actions involve efforts to calm down the border society members, maintain safe condition, stop all physical developments such as road development, government office, citizen residential and agricultural 
development in the border area. Long term actions involve diplomatic efforts to delimit boundary segments that are disagreed yet by the two countries. Diplomatic efforts include identification of boundary regulation that enables citizens from both sides to maintain their social relationships and family ties (Website Sekneg, 20th March 2013), however, there remains different patterns of approach from each government to resolve the border conflict. Timor Leste government emphasizes more on the use of 1904 Treaty, not social cultural values, and customary law, whereas Indonesia emphasizes more on social and cultural values, family ties and customary law. Efforts to match these different perceptions are very important to reach an effective resolution.

Related to border conflict segments that are unresolved yet completely, Indonesian governments at all level have undertaken several policy initiatives. Specifically, in Naktuka, Kupang District, Indonesia and Citrana, Oecusse District, Timor Leste, district government of Kupang has done several policy actions such as :

- Conducting coordination meeting with customary figures and society prominent figures from East Amfoang, Kupang District to discuss border conflict resolution from social cultural aspect and customary law, collecting data and matching perceptions regarding territorial boundaries of exAmfoang empire (Indonesia) and ex-Ambeno empire (Timor Leste), and writing a historical book of ex-Amfoang empire (Indonesia) as references to support the process of border conflict resolution.

- Suggesting to Indonesian central government the use of customary law as an important resolution way because society members from both sides still have strong family ties, similar social cultural values and custom.

- Using customary approach to prevent border conflict continuation.

At the level of district government of North Middle Timor, efforts to reach border conflict resolution include :

- Conducting a meeting with customary figures, society prominent figures from both sides, provincial government of East Nusa Tenggara, district government of Kupang and Oecusse, Timor Leste, to discuss and determine the two state boundaries, however agreement is unreached because each side still holds out.

- Communicating continuously with Indonesian central government to conduct public hearing with border society members, appealing them to remain quiet, and awaiting conflict resolution process and result.

- In 2015, the provincial government of East Nusa Tenggara and district government of North Middle Timor tried to build a compassion border monument between Sunsea village, North Middle Timor District, Indonesia and Kosta village,
Oecusse District, Timor Leste, but Timor Leste government diagreed so that the monument could not be built.

- The government shapes three mediation forums that are BLOC (border liasion organizing committee) with duty to negotiate with society members in conflict region, PBLC (provincial border liasion committee) with duty to negotiate with Indonesian central government, and JBC (Jakarta border liasion committee) with duty to do diplomacy and negotiation with Timor Leste government.

At the level of provincial government, the provincial government of East Nusa Tenggara invites the Ministry of Domestic Affairs and Foreign Affairs to conduct survey at border conflict points that will be used to do diplomacy and negotiation with Timor Leste government. According to the head of border management board of East Nusa Tenggara province, the provincial government of East Nusa Tenggara, and district government of Kupang and North Middle Timor had done coordination meeting with Indonesian central government, customary figures and society prominent figures to discuss border conflict resolution in Kefamenanu, North Middle Timor District, Indonesia in April 2016. The provincial government of East Nusa Tenggara also did a meeting with customary figures involving all ex-kingdoms of Timor island to discuss the resolution of border conflict Naktuka and Citrana on 8th September 2016.

At the national level, Indonesian central government (cq. Ministry of Foregin Affairs) has done several preparations for diplomacy with Timor Leste government that are : (1) coordination with related state institutions (Ministry of Domestic Affairs, and Coordinator Ministry of Politics, Law and Defense); (2) joint field survey on unresolved segments, notably Naktuka-Citrana and Bijaelsunan-Oben by engaging Indonesia and Timor Leste authority, and border society members who own customary land in border conflict areas; (3) consultation with Timor Leste government regarding unresolved segments; (4) discussing every things related to international law and history; (5) collaborate with Timor Leste government to build society member understanding regarding resided land; (6) proposing objection to Timor Leste government regarding infrastructure development in border conflict areas, requiring Timor Leste government to not do more development activities until delineation process finishes and at the mean time infrastructure development has stopped (Aria Triyudha; IRIB Indonesia/Viva/ RA, January 2016).

However, customary figures and society prominent figures always question the result of Indonesian government diplomacy with Timor Leste government regarding border conflict resolution especially Naktuka and Citrana. They assume that Indonesian government is slightly slow in resolving Naktuka and Citrana border conflict (Kompas.com. 8th September 2016). On the other hand, the head of border management board of East Nusa Tenggara province stated that Indonesian government through Ministry of Foreign Affairs has sent protest note to Timor Leste government, and has done diplomacy, but it is still unsuccessful yet to convince Timor 
Leste government in resolving unresolved segments because the two governments still have different perceptions regarding the unresolved segments (KBR NTT, 14th September 2016).

\section{CONCLUSION}

Although Indonesian governments at all levels have done a number of policy actions to manage and resolve the border conflict between Indonesia and Oecusse District, Timor Leste, the result of conflict management and resolution is still unclear. Meanwhile, customary figures and society prominent figures in border conflict areas from Indonesian side require Indonesian government to make clear result of the border conflict management and resolution. Indonesian government should continuously do diplomacy and negotiation with Timor Leste government to manage and resolve border conflict between the two countries by considering simultaneously several aspects such as administrative/politics, border history, social and cultural values, customary law, equity and togetherness.

\section{REFERENCES}

[1] Ansyari, Syahrul \& Nadlir, Moh. 2016. Sejarah Munculnya Sengketa Wilayah Indonesia- Timor http://nasional.news.viva.co.id/news/read/725771

[2] Birkland, T. A. 2005. An Introduction to the policy process : theories, concepts and models of public policy making (2nd ed.).M.E. Sharpe. London, England.

[3] Creswell, J. W. 2013. Qualitative inquiry and research design: choosing among five approaches. Sage Publication Inc. London.

[4] Dye, T. R. 2002. Understanding public policy. Prentice Hall. New Jersey.

[5] Fenn, Peter \& Gameson, Rod. 1992. Construction Conflict Management and Resolution. E \& FN SPON. London.

[6] Fenn, Peter., O’Shea, Michael. \& Davies, Edward. 1998. Dispute Resolution and Conflict Management in Construction: An international review. E \& FN Spon, An imprint of Routledge. London.

[7] Hernandez, Burhan. 2015. Analisa Konflik Perbatasan Indonesia Timor http://www.kompasiana.com/www.burhanhernandez.com/analisakonflik-perbatasan-indonesia-timor-leste_5559e93ab67e610c7dd366af

[8] Kraft, M. E., \& Furlong, S. R. 2007. Public policy : politics, analysis and alternatives (2nd ed.). CO Press. Washington, D.C.

[9] Lyons, Terrence \& Khadiagala, Gilbert, M. 2008. Conflict Management and African Politics : Ripeness, bargaining, and mediation. Routledge. New York.

[10] Milles, B. M., \& Huberman, A. M. 1992. Qualitative data analysis. Sage Publication Inc. Thousand Oaks.

[11] Moleong, Lexy J. 2007. Metodologi Penelitian Kualitatif. PT Remaja Rosdakarya. Bandung.

[12] Pal, L. A. 2006. Beyond Policy Analysis : Public Issue Management in Turbulence Time (3rd Ed.). Thomson Nelson. Canada.

[13] Pammer, William J., \& Killian, Jr. Jerri. 2003. Handbook of Conflict Management. Wright State University. Dayton, Ohio, U.S.A.

[14] Raharjo, Sandy Nur Ikfal. 2013. Konflik Komunal di Perbatasan Indonesia-Timor Leste dan Upaya Penyelesaiannya. http://www.politik.lipi.go.id/kolom/kolom-1/politik-internasional/899konflik-komunal-di-perbatasan-indonesia-timor-leste-dan-upayapenyelesaiannyaPolitik Internasional

[15] Rahim, M. Afzalur. 2001. Managing Conflict in Organizations (Third Edition). London : QUORUM BOOKS

[16] Sanginga, Pascal, C., Kamugisha, N. Rick, \& Martin, Andrienne M. 2007. The Dynamics of Social Capital and Conflict Management in Multiple Resource Regimes: A Case of the Southwestern Highlands of Uganda. Ecology and Society 12(1): 6. [online] URL: http://www.ecologyandsociety.org/vol12/iss1/art6/

[17] Subar. 2016. Implementasi Strategi Pengamanan dan Pembinaan Teritorial Perbatasan Republik Indonesia dengan Republik Demokratik Timor Leste (Studi Kasus Perbatasan Kecamatan Amfoang Timur Kabupaten Kupang. Tesis. Program Pascasarjana Universitas Nusa Cendana, Kupang.

[18] Sugiyono. 2013. Metode penelitian kombinasi (mixed methods). Penerbit Alfabeta. Bandung.

[19] Suryanto. 2009. Deplu Survei Perbatasan RI-Timor Leste. http://www.antaranews.com/berita/152327/deplu-survei-perbatasan-ritimor-leste

[20] Timor Express. 2016. Lembaga Pemangku Adat (LPA) Amfoang Gelar Musyawarah Agung. Kupang. 04 Mei. 